\title{
Complexes of Chromium with $\beta$-Glycerophosphate: Their Nature and Properties
}

\author{
Leopoldo J. ANGHileri * \\ The Johns Hopkins Medical Institutions Baltimore, Maryland USA ** \\ (Z. Naturforsch. 25 b, 288-292 [1970] ; eingegangen am 13. November 1969)
}

\begin{abstract}
By ion echange analysis, dialysis and electrophoresis of double labelled $\left({ }^{32} \mathrm{P}\right.$ and ${ }^{51} \mathrm{Cr}$ ) chromic $\beta$-glycerophosphate complexes, the stability of the bond $\beta$-glycerophosphate-chromium under different conditions of olation and oxolation has been studied. The glycerophosphate can form complexes with 1 or 2 moles per chromium atom. Below pH 6.0 the complexes present cationic characteristics, while between $\mathrm{pH} 6.0$ and $\mathrm{pH} 8.0$ they behave as anions. The oxolation provokes a release of $\beta$-glycerophosphate from the complex. The physicochemical characteristics of these complexes are reflected in their behaviour "in vivo" when injected into mice.
\end{abstract}

In the search for a radioactive compound which, on a metabolic basis, will produce an accumulation of radioactivity "in situ" allowing the scintigraphic scanning or localization of a tumor, the ${ }^{51} \mathrm{Cr}$ - $\beta$-glycerophosphate complex has been developed. Previous experimental work ${ }^{1-5}$ has indicated that this compound possesses good properties for a tumor localizing agent.

Considering that a thorough study of the chemical and physicochemical processes involved in preparing this complex would provide a better understanding of its biological behaviour, this experimental study was undertaken.

\section{Material and Methods}

\section{a) Preparation of uncomplexed chromic $\beta$-glycero- phosphate}

Stoichiometric quantities (i. e. $0.3 \mathrm{mmol}$ in $5 \mathrm{ml}$ volume) of sodium $\beta$-glycerophosphate and chromic chloride were mixed at room temperature and immediately a bulky metallic silver gray precipitate of chromic $\beta$-glycerophosphate (1) was formed. This precipitate was washed four times with ice cold distilled water.

\section{b) Preparation of complexed chromic $\beta$-glycero- phosphate}

An aqueous suspension of (1) was heated in a boiling water bath. The precipitate readily dissolved giving a deep emerald green solution and the $\mathrm{pH}$ decreased from $5.0-5.2$ to $2.0-2.2$. After 10 minutes of

* Present address: Division of Nuclear Medizine, University of Colorado Medical Center, Denver, Colorado 80220, USA.

** Supported by U.S.P.H.S. Grant G.M. 10548.

1 L. J. ANghileri, Oncology 21, 275 [1967].

2 L. J. ANGhileri, Naturwissenschaften, Heft 3, S. 136 [1968]. heating the solution was cooled to $5-10{ }^{\circ} \mathrm{C}$ and its $\mathrm{pH}$ readjusted with $1 \mathrm{~m} \mathrm{NaHCO}_{3}$. A perfectly clear solution (2) was obtained after neutralization, even at $\mathrm{pH}$ 8.2. Uncomplexed chromium precipitates at about $\mathrm{pH} 4.5-5.0$.

\section{c) Olated and Oxolated complexes}

If the neutralization of $(\mathbf{2})$ is carried out at different $\mathrm{pH}$ values, a different degree of cationic aggregation is provoked. Also, if this neutralization is accompanied by heating, a higher degree of polymerization (oxolation) is reached.

In all these preparation, the incorporation of ${ }^{51} \mathrm{Cr}$ as $\mathrm{CrCl}_{3}$ has permitted the radioactive tagging of the complex.

In order to study the stability of the $\beta$-glycerophosphate-chromium bond, similar complexes were prepared using ${ }^{32} \mathrm{P}-\beta$-glycerophosphate.

\section{d) Inonic exchange analysis}

One tenth $\mathrm{ml}$ samples of each preparation were passed through small columns $(7 \mathrm{~cm} \times 0.7 \mathrm{~cm})$ of anion exchange resin (Dowex 1-X8, chloride form) and cation exchange resin (Dowex 50-X-, sodium form). The radioactivity in the eluate as well as that retained on the resins was measured.

\section{e) Dialysis experiments}

Two tenths ml samples oft he complex were dialyzed for 48 hours against distilled water (with a least 8 changes of the dialysis liquid). The radioactivity on the dialysis bag, as well as an aliquot of the dialysate were counted.

3 L. J. Anghileri, Nuclear Med. [Stuttgart] VII, 266 [1968].

${ }^{4}$ L. J. Anghileri, Z. Krebsforsch. 72, 350 [1969].

5 L. J. Anghileri, R. C. Reba, and H. N. Wagner, Invest. Radiol. 4, 91 [1969]. 


\section{f) Electrophoretic experiments}

Twenty to fifty $\mu$ l samples were analyzed by 1 hour electrophoresis on Whatman 3MM paper, using $0.02 \mathrm{M}$ $\mathrm{NaHCO}_{3}$ as a buffer and a voltage gradient of $16-18$ $\mathrm{V} / \mathrm{cm}$. The radioactivity distribution pattern was determined by cutting $1 \mathrm{~cm}$ pieces of the electrophoretic strip and counting for ${ }^{51} \mathrm{Cr}$ in a well counter and for ${ }^{32} \mathrm{P}$ in a liquid scintillation counter ${ }^{6}$.

g) Assay of the conversion of $\beta$-glycerophosphoric acid into the a-form

The possible transposition of the $\beta$-isomer into the $\alpha$-isomer was assayed according to the method of FLEURY ${ }^{7}$ based on the action of $\mathrm{HIO}_{4}$ on the polyhydroxyl compounds.

\section{h) Study of the animal distribution}

Groups of mice $(20-25 \mathrm{gm}$ body weight) were injected intravenously with $0.1 \mathrm{ml}$ of aliquots of labelled complex. The animals were sacrified at different intervals and the radioactivity of various organs and tissues counted in a well counter. oFr whole body counding animals in one group were counted in a large well counter at intervals for 15 days.

\section{Results and Discussion}

The solubility of the uncomplexed chromic $\beta$-glycerophosphate in $100 \mathrm{ml}$ of water was determined as: $0.210 \mathrm{gm}$ at $4{ }^{\circ} \mathrm{C}$ and $0.335 \mathrm{gm}$ at $25^{\circ} \mathrm{C}$. The $\mathrm{pH}$ of this solution was $5.0-5.2$. After complexing the chromium by boiling, its solubility at $4{ }^{\circ} \mathrm{C}$ increases to $10.050 \mathrm{gm}$ and at $25^{\circ} \mathrm{C}$ to $13.550 \mathrm{gm}$, while the $\mathrm{pH}$ falls to $2.0-2.2$. The influence of the heating in the complex formation can be interpreted as follows:

$$
\begin{aligned}
& {\left[\mathrm{Cr}\left(\mathrm{H}_{2} \mathrm{O}\right)_{6}\right] \mathrm{Cl}_{3}+\mathrm{Na}_{2} \beta-\mathrm{GPA} * \rightarrow} \\
& {\left[\mathrm{Cr}\left(\mathrm{H}_{2} \mathrm{O}\right)_{6}\right] \beta \mathrm{GPA} \mathrm{Cl}+2 \mathrm{NaCl} \text {. }} \\
& \text { (1) } \\
& {\left[\mathrm{Cr}\left(\mathrm{H}_{2} \mathrm{O}\right)_{6}\right] \mathrm{GPA}, \mathrm{Cl} \stackrel{\text { heat }}{\longrightarrow} \rightarrow} \\
& {\left[\mathrm{Cr}\left(\mathrm{H}_{2} \mathrm{O}\right)_{4} \beta \mathrm{GPA}\right] \mathrm{Cl}+2 \mathrm{H}_{2} \mathrm{O} \text {. }}
\end{aligned}
$$

This process known as anion penetration ${ }^{8}$ is similar to the tetra-aquo chromic chloride ion formation after heating of a chromic hexahydrate chloride solution ${ }^{9}$.

6 T. Clausen, Analytic. Biochem. 22, 770 [1968].

7 P. Fleury, J. Pharmac. Chim. 18, 470 [1933].

$* \beta \mathrm{GPA}=\beta$-Glycerophosphate.

8 F. G. R. Gimblett, in: Inorganic Polymer Chemistry, p. 104, Butterworths and Co. (Publishers), London 1963.
Both forms (1) and (2) are insoluble in ethanol. The dehydration of the form (2) with either ethanol or acetone produces a light green powder. This dissolves slowly in water after a hydration characterized by swelling to a deep green gel-like material.

Electrophoretically, form (2), shows a higher mobility toward the anode. Neutrabized to $\mathrm{pH} 5.0$, it migrates approximately $5-6 \mathrm{~cm}$, while the form (1) moves only $1-2 \mathrm{~cm}$ after a lhour run using $0.02 \mathrm{M} \mathrm{NaHCO}_{3}$ as buffer and a voltage gradient of $16 \mathrm{~V} / \mathrm{cm}$.

Olation is the process of formation of polynuclear species in which the metal atoms are bound by diol (dihydroxo) bridges. By heating, prolonged aging and/or high $\mathrm{pH}$ these polynuclear species can be modified by the elimination of a molecule of water between two adjacent hydroxo bidges with the consequently formation of an $\mathrm{Me}-\mathrm{O}-\mathrm{Me}$ bond. This process is called oxolation ${ }^{10}$. In this case both processes can be described as follows:

\section{Olation}

$$
\begin{aligned}
& {\left[\mathrm{Cr}(\beta \mathrm{GPA})\left(\mathrm{H}_{2} \mathrm{O}\right)_{4}\right]^{3 \oplus} \rightleftarrows} \\
& {\left[\mathrm{Cr}(\beta \mathrm{GPA})\left(\mathrm{H}_{2} \mathrm{O}\right)_{3} \mathrm{OH}\right]^{2 \oplus}+\mathrm{H}^{\oplus} \text {. }} \\
& {\left[\mathrm{Cr}(\beta \mathrm{GPA})\left(\mathrm{H}_{2} \mathrm{O}\right)_{4}\right]^{3 \oplus}+\left[\mathrm{Cr}(\beta \mathrm{GPA})\left(\mathrm{H}_{2} \mathrm{O}\right) \mathrm{OH}\right]^{2 \oplus} \rightarrow} \\
& \rightarrow\left[(\beta \mathrm{GPA})\left(\mathrm{H}_{2} \mathrm{O}\right)_{3} \mathrm{Cr} \backslash \mathrm{Cr}\left(\mathrm{H}_{2} \mathrm{O}\right)_{3}(\beta \mathrm{GPA})\right]^{5 \oplus}+\mathrm{H}_{2} \mathrm{O} \text {. } \\
& \mathrm{O} \\
& \rightarrow\left[(\beta \mathrm{GPA})\left(\mathrm{H}_{2} \mathrm{O}\right) \mathrm{Cr} \underset{\mathrm{H}}{\mathrm{O}} \underset{\mathrm{O}}{\mathrm{O}}>\mathrm{Cr}\left(\mathrm{H}_{2} \mathrm{O}\right)_{2}(\beta \mathrm{GPA})\right]^{4 \oplus} \\
& +2 \mathrm{H}_{2} \mathrm{O} \text {. }
\end{aligned}
$$

\section{Oxolation}

$$
\begin{aligned}
{\left[(\beta \mathrm{GPA})\left(\mathrm{H}_{2} \mathrm{O}\right)_{2} \mathrm{Cr}<\mathrm{O}\right.} & \left.\begin{array}{c}
\mathrm{O} \\
\mathrm{O}
\end{array}>\mathrm{Cr}\left(\mathrm{H}_{2} \mathrm{O}\right)_{2}(\beta \mathrm{GPA})\right]^{4 \oplus} \rightleftarrows \\
\mathrm{H} & \\
{\left[(\beta \mathrm{GPA})\left(\mathrm{H}_{2} \mathrm{O}\right)_{2} \mathrm{Cr}<\mathrm{O}\right.} & \left.>\mathrm{Cr}\left(\mathrm{H}_{2} \mathrm{O}\right)_{2}(\beta \mathrm{GPA})\right]^{2 \oplus} \\
& +2 \mathrm{H}^{\oplus} .
\end{aligned}
$$

The increase of acidity (release of protons) observed during the preparation of the form (2) is undoubtedly an indication that these processes (particularly olation) are involved in the complex formation.

9 F. Ephraim, in: Inorganic Chemistry, 6th English Ed., p. 314, Oliver and Boyd, London 1954.

10 F. G. R. Gimblett, in: Inorganic Polymer Chemistry, p. 77, Butterworths and Co., London 1963. 
By submitting the form (2) of double labeled $\left({ }^{32} \mathrm{P}\right.$ and ${ }^{51} \mathrm{Cr}$ ) chromic complex to various degrees of cationic aggregation (increasing of $\mathrm{pH}$ with and without heating) the stability of the bond $\beta$-glycerophosphate-chromium was studied. Ionic exchange analysis, dialysis and electrophoresis were used to determine to what extent the ${ }^{32} \mathrm{P}$ remains bound to

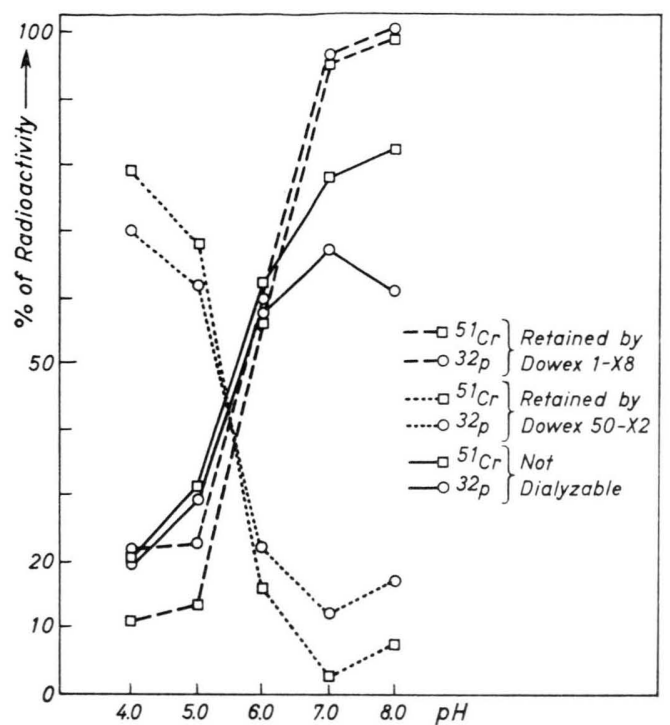

Fig. 1. Ion exchange analysis and dialysis values of ${ }^{32} \mathrm{P}^{51} \mathrm{Cr}$ chromic $\beta$-glycerophosphate complexes prepared at different pH's.

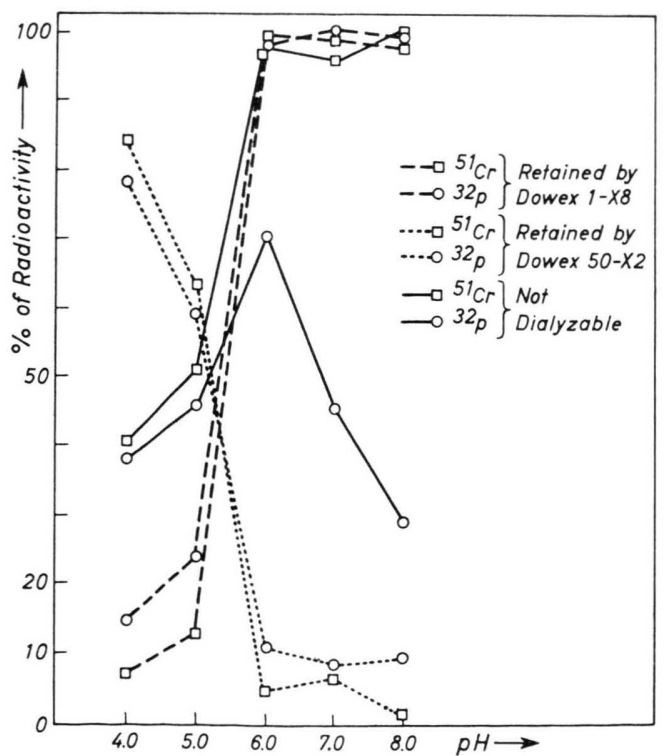

Fig. 2. Ion exchange analysis and dialysis values of ${ }^{32} \mathrm{P}^{51} \mathrm{Cr}$ chromic $\beta$-glycerophosphate complexes prepared at different $\mathrm{pH}$ 's and heated to provoke cation aggregation. the ${ }^{51} \mathrm{Cr}$ under these different conditions. Figs. 1 and 2 show the results of ion exchange analysis and dialysis for complexes prepared at different $\mathrm{pH}$ values, without (Fig. 1) and with (Fig. 2) heating to provoke cationic aggregation. These results indicate that the non-dialyzable amount of ${ }^{32} \mathrm{P}$ increases sharply between $\mathrm{pH} 5.0$ and $\mathrm{pH} 6.0$ while between $\mathrm{pH} 6.0$ and $\mathrm{pH} 8.0$ this increase is much lower. The heating also provokes an increase of non-dialyzable ${ }^{32} \mathrm{P}$ between $\mathrm{pH} 4.0$ and $\mathrm{pH} 6.0$, but a significant decrease at higher pH's. On the other hand, the chromium behaviour is similar, but with the characteristic that above $\mathrm{pH} 6.0$ the non-dialyzable fraction increases considerably. If oxolation was produced by heating, the amount of ${ }^{51} \mathrm{Cr}$ complex reaches a value of almost $100 \%$ while ${ }^{32} \mathrm{P}$ complex decreases.

The amount of ${ }^{32} \mathrm{P}$ retained by Dowex 1 (anion exchange resin) increases from $23 \%$ to approximately $100 \%$ when the $\mathrm{pH}$ is raised to 7.0 , while the amount retained by Dowex 50 (cation exchange resin) decreases from $70 \%$ to 16 per cent. When the complex has been heated, the amount of ${ }^{32} \mathrm{P}$ retained by Dowex 1 increases sharply to almost $100 \%$ at $\mathrm{pH}$ 6.0, but with Dowex 50, it shows a pattern similar to that of the unheated complex; i. e. a decrease from $70-80 \%$ at $\mathrm{pH} 4.0$ to $10-20 \%$ at $\mathrm{pH}$ 6.0 and practically no significant change at higher $\mathrm{pH}$ 's.

The behaviour of the ${ }^{51} \mathrm{Cr}$ with the ion exchange analysis is strikingly similar to that of the ${ }^{32} \mathrm{P}$. The most noticeable difference is that between $\mathrm{pH} 6.0$

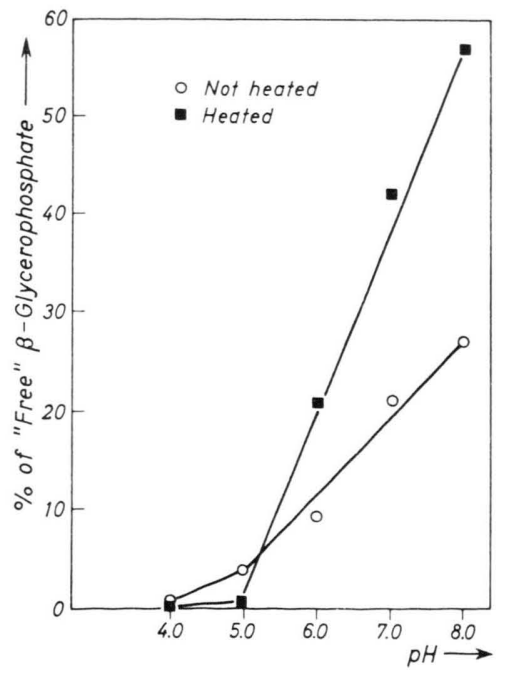

Fig. 3. Electrophoretic analysis of chromic $\beta$-glycerophos. phate complexes prepared at different $\mathrm{pH}$ 's and with or without provoked cation aggregation. 
and $\mathrm{pH} 8.0$, the amount of ${ }^{32} \mathrm{P}$ retained by Dowex 50 is slightly higher than the amount of ${ }^{51} \mathrm{Cr}$.

The electrophoretic determination of free- $\beta$-glycerophosphate (not bound to chromium) shows a progressive increase with increased $\mathrm{pH}$, which is still higher (approximately twice) when the preparations are heated (Fig. 3).

We can summarize the results of dialysis, ion exchange analysis and electrophoresis as follows: Under $\mathrm{pH} 5.0$ the complex behaves as a cation, then there is a transition zone ( $\mathrm{pH} 5.0$ to 6.0), and over $\mathrm{pH} 6.0$ the complex behaves as an anion. The $\beta$-glycerophosphate molecule seems to be tightly bound to the chromium and it is partially released only when the complex is submitted to a drastic cation aggregation (oxolation) by heating. Consequently with the release of $\beta$-glycerophosphate, the insolubilization of the chromium is enhanced.

Similarly, using the electrophoretic technique, preparations made with increasing ratios of $\mathrm{Na}-\beta$ glycerophosphate to chromium ( 1 to 6 ) have shown that only complexes with 1 or 2 molecules of $\beta$-glycerophosphate per atom of chromium are formed (Fig. 4).

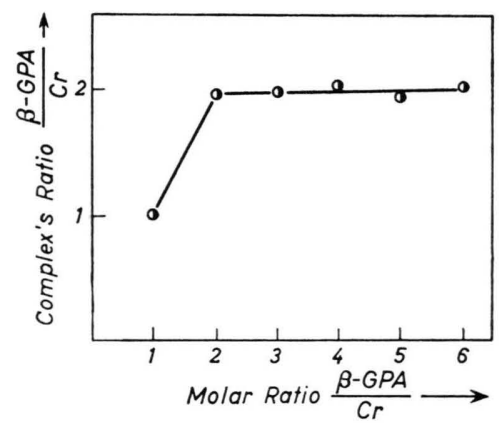

Fig. 4. Effects of the ratio $\beta$-glycerophosphate to chromium in the composition of the chromic $\beta$-glycerophosphate complex.
Considering the possibility that the sharp decrease in $\mathrm{pH}(1.1-1.2)$ and heating during the complex formation could provoke the conversion of $\beta$-glycerophosphate into the $\alpha$-form ${ }^{12,13}$, the $\alpha$-glycerophosphate was measured as described elsewhere ${ }^{7}$. No formation of the $\alpha$-form was detected, which is an indication that the acidity is not enough to catalyze that transformation.

From the biological point of view there is a well defined pattern closely related to the physicochemical properties of the complexes. As can be seen in Tables I and II the increasing of $\mathrm{pH}$ and/or heating raises the amount of radioactivity taken up by the R.E.S.(liver) while diminishing the bone uptake. Both phenomena are caused mainly by the polymerization of the chromic- $\beta$-glycerophosphate complex, which by progressive aggregation reaches a colloidal

\begin{tabular}{lccr}
\hline & $\begin{array}{c}\text { Un- } \\
\text { complexed }\end{array}$ & $\begin{array}{c}\text { Complexed } \\
\mathrm{pH} 5.0\end{array}$ & $\begin{array}{c}\text { Complexed } \\
\mathrm{pH} \text { 5.0 } \\
+ \text { heating }\end{array}$ \\
\hline Blood & $\mathbf{1 . 3 4 \pm 0 . 2 9}$ & $0.31 \pm 0.08$ & $0.20 \pm 0.04$ \\
Liver & $1.62 \pm 0.76$ & $4.38 \pm 1.17$ & $23.05 \pm 0.94$ \\
Kidneys & $\mathbf{1 . 7 5} \pm 0.53$ & $0.27 \pm 0.02$ & $0.49 \pm 0.04$ \\
Lungs & $1.39 \pm 0.44$ & $0.20 \pm 0.12$ & $0.36 \pm 0.18$ \\
Spleen & $1.44 \pm 0.51$ & $2.66 \pm 1.02$ & $6.12 \pm 1.36$ \\
Bone & $9.73 \pm 0.87$ & $2.27 \pm 0.92$ & $1.99 \pm 0.30$ \\
\hline
\end{tabular}

Table I. Radioactivity distribution 24 hours after intravenous injection of different types of ${ }^{51} \mathrm{Cr}$ - $\beta$-glycerophosphate (as percentage of injected dose per gram of tissue) in groups of 4 animals.

form (becoming non-dialyzable around 100\%) that is retained to a higher extent by the Kupffer cells. On the other hand, this polymerization removes the cationic characteristics of the chromium complex and consequently its ability to exchange with calcium and magnesium of the mineral bone tissue ${ }^{11}$. As has

\begin{tabular}{lcccccc}
\hline & $\mathrm{pH} 4.8$ & $\begin{array}{c}\mathrm{pH} \mathrm{4.8} \\
\text { w. heating }\end{array}$ & $\mathrm{pH} \mathrm{6.0}$ & $\begin{array}{c}\mathrm{pH} 6.0 \\
\text { w. heating }\end{array}$ & $\mathrm{pH} \mathrm{8.0}$ & $\begin{array}{c}\mathrm{pH} 8.0 \\
\text { w. heating }\end{array}$ \\
\hline Blood & $1.22 \pm 0.19$ & $0.56 \pm 0.07$ & $1.00 \pm 0.22$ & $0.79 \pm 0.22$ & $0.42 \pm 0.09$ & $0.11 \pm 0.05$ \\
Tumor & $1.21 \pm 0.47$ & $0.50 \pm 0.12$ & $1.08 \pm 0.34$ & $0.65 \pm 0.11$ & $1.12 \pm 0.66$ & $0.18 \pm 0.14$ \\
Brain & $0.04 \pm 0.02$ & $0.02 \pm 0.01$ & $0.03 \pm 0.005$ & $0.02 \pm 0.005$ & $0.02 \pm 0.005$ & $0.34 \pm 0.12$ \\
Muscle & $0.37 \pm 0.21$ & $0.19 \pm 0.11$ & $0.21 \pm 0.07$ & $0.09 \pm 0.02$ & $0.19 \pm 0.07$ & $0.42 \pm 0.16$ \\
Bone & $18.2 \pm 5.55$ & $4.78 \pm 0.74$ & $11.9 \pm 4.88$ & $2.33 \pm 1.08$ & $5.11 \pm 0.49$ & $5.61 \pm 0.27$ \\
Liver & $0.72 \pm 0.19$ & $0.32 \pm 0.01$ & $0.96 \pm 0.52$ & $1.14 \pm 0.13$ & $39.6 \pm 2.91$ & $47.5 \pm 4.76$ \\
\hline
\end{tabular}

Table II. Radioactivity distribution in different tissues 6 hours after intravenous injection of ${ }^{51} \mathrm{Cr}$ - $\beta$-glycerophosphate in mice bearing experimental brain tumors (ependymamas). The values are the percentage of injected dose per gram of tissue in groups of 3 animals.

11 L. J. ANGhileri, Experientia [Basel] 25, 283 [1969].

13 E. Chargaff, J. biol. Chemistry 144, 455 [1942].

12 M. C. Bailly, C. R. hebd. Séances Acad. Sci. 206, 1902

[1938]. 


\begin{tabular}{|c|c|c|c|c|}
\hline & \multicolumn{2}{|c|}{ Ratio $1: 1$} & \multicolumn{2}{|c|}{ Ratio $1: 2$} \\
\hline Blood * & $0.11 \pm 0.04$ & $0.15 \pm 0.05$ & $0.03 \pm 0.02$ & $0.05 \pm 0.02$ \\
\hline Liver & $0.31 \pm 0.01$ & $1.44 \pm 0.15$ & $7.45 \pm 0.47$ & $3.44 \pm 0.05$ \\
\hline Kidneys & $0.43 \mp 0.03$ & $0.37 \mp 0.04$ & $0.67 \pm 0.08$ & $0.54 \pm 0.04$ \\
\hline Lungs & $0.03 \pm 0.01$ & $0.07 \pm 0.03$ & $0.10 \pm 0.02$ & $0.08 \pm 0.02$ \\
\hline Spleen & $0.02 \pm 0.01$ & $0.05 \pm 0.02$ & $0.33 \pm 0.06$ & $0.16 \pm 0.01$ \\
\hline Bone* & $4.36 \pm 1.24$ & $1.78 \pm 0.38$ & $4.01 \pm 0.78$ & $3.65 \pm 0.18$ \\
\hline * Percen & of dose per & & & \\
\hline
\end{tabular}

Table III. Influence of the ratio of chromium to $\beta$-glycerophosphate in the biological behaviour of ${ }^{51} \mathrm{Cr}-\beta$. glycerophosphate complex (Groups of 4 animals sacrificed 24 hours after intravenous injection and as percentage of injected dose per organ).

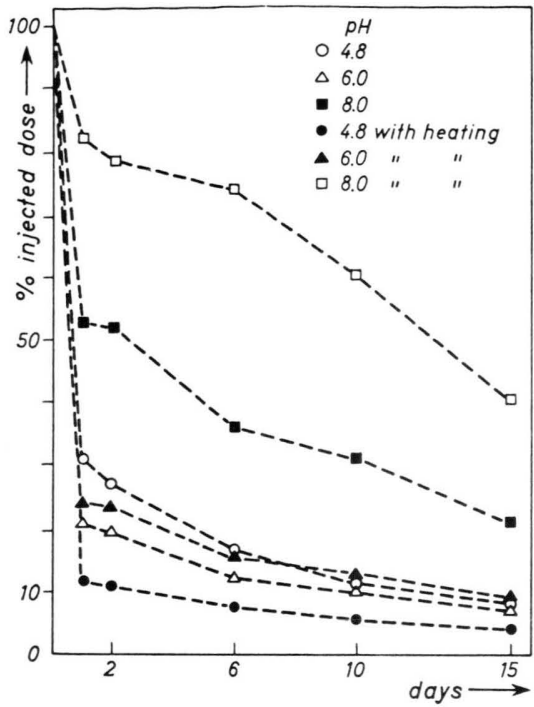

been seen before, the increase of $\mathrm{pH}$ and heating lowers the amount of $\beta$-glycerophosphate in the com. plex and the two combined effects consequently reduce its availability for metabolic processes. This situation is reflected in the tumor uptake (Table II). Similarly, the number of molecules of $\beta$-glycerophosphate incorporated into the chromium complex seems to influence the biological fate of the chromium (Table III).

This direct relationship between cation aggregation and biological behaviour also is corroborated by the whole body counting (Fig. 5) where a higher polymerization corresponds with a higher radioactivity retention by the whole body.

Fig. 5. Whole body counting at different time intervals after intravenous injection of different ${ }^{51} \mathrm{Cr}$ - $\beta$-glycerophosphate preparations.

\title{
Inhibitoren der Nucleosidphosphorylierung in vivo
}

\author{
Inhibitors of Nucleoside Phosphorylation in vivo \\ Jörg Rau und Christoph Scholtissek \\ Institut für Virologie, Justus Liebig-Universität, Gießen \\ (Z. Naturforsch. 25 b, 292-299 [1970] ; eingegangen am 27. November 1969)
}

\begin{abstract}
Acridinorange and pyronine inhibit the uptake and phosphorylation of nucleosides. The same doses of inhibitor do not yet interfere with RNA synthesis. An inhibition of similar specificity concerning nucleoside uptake is observed by several pyrimido-pyrimidine and pteridine derivatives. This inhibition can be reversed only by such nucleosides which are phosphorylated by the same nucleoside kinase. Several nucleoside analogues were also tested. We conclude that the inhibitors are interfering with the kinase reaction in vivo.

The propagation of fowl plague virus (KP) is inhibited only by high doses of pyronine, yet neither by the pyrimido-pyrimidines nor the pteridines tested.
\end{abstract}

In letzter Zeit sind eine Reihe von Substanzen untersucht worden, die eine spezifische Hemmung der Aufnahme von Nucleosiden in Gewebekulturzellen zeigen. Diese Wirkung wurde bei Acridin-Deri- vaten mit sekundärer oder tertiärer Aminogruppe und Pyronin ${ }^{1}$ und bei 2-Mercapto-1-( $\beta$-4-pyrid-

1 C. Scholtissek u. H. Becht, Biochim. biophysica Acta [Amsterdam] 123, 585 [1966]. 